\title{
Transforming Pedagogical Approaches Using Tangible User Interface Enabled Computer As- sisted Learning
}

\author{
http://dx.doi.org/10.3991/ijet.v10i6.4865
}

\author{
A. Istenič Starčič ${ }^{1}, 2,3$, Ž. Turk ${ }^{1}$ and M. Zajc ${ }^{1}$ \\ ${ }^{1}$ University of Ljubljana, Ljubljana, Slovenia \\ ${ }^{2}$ University of Primorska, Koper, Slovenia \\ ${ }^{3}$ Macquarie University, Sydney, NSW Australia
}

\begin{abstract}
Traditional computer assisted learning is influenced by novel user interfaces, such as tangible user interfaces, support cognitive processes and concept modelling, assisted by multiple representation. The manipulative properties of the tangible user interface's physical manipulatives, for example, enhance passage between physical and virtual representations. It therefore provides a transition between stages in the reasoning process. In social modes of learning, physical manipulatives provide assistance in all social modes: individual, pairs, small groups and teacher up front. Computer supported collaborative learning is provided in the physical presence of learners manipulating on the same tabletop device. A systematic review of scientific articles applying qualitative and quantitative approaches was undertaken. The content analysis was conducted to examine pedagogical approaches based on the two models of Bruner (1966) and Gagné (1985).
\end{abstract}

Index Terms-Computer assisted learning, Representations in learning, Socio-cultural theories of learning and instruction, Tangible interaction, Tangible user interface.

\section{INTRODUCTION}

Contemporary society is facing demands to enhance learning processes to achieve high learning outcomes and learner competence whilst recognising learners' diversity and accessibility needs. The interface between human and computer is an essential part of this process, providing technology accessibility and new approaches to learning and teaching. Education in general and computer education in particular are facing severe changes $[1,2]$. Globally, researchers are investigating new ways to bring computer literacy to everyone. Many forms go far beyond the typical classroom format, including a variety of learning and teaching methods and learning environments. "Demand pull" for high quality, timely and relevant education is higher than ever.

Education is, however, also being affected by the "technology push". Because communication, construction and circulation of information and knowledge are part of cognition and learning, teaching and learning are being affected by the dramatic changes in communication technology. Like any other field that is involved with construction, circulation of information and networking, education is also being disrupted by new technologies. It is being affected in a similar way to other communication and information industries such as telecommunication, media and entertainment.

In this paper, we focus on how a very specific technology - that of tangible user interface (TUI) - can be used to enhance teaching and learning. In the next section we present the technology itself and in section 3 we present a conceptual model that deploys theories of learning and instruction, providing a framework for classification and analysis of the TUI in teaching and learning. Against this background, state of the art in teaching and learning using touch technology is presented in Section 4. A review of articles about the use of TUI in web of Science, IEEE Explore, ACM Digital Library, Springer, Elsevier was undertaken. Findings are presented and analysed in the Section 6.

Pervasive computing is changing traditional computer assisted learning. Novel user interfaces support cognitive processes and concept modelling, assisted by multiple representation. The manipulative properties of the tangible user interface's physical manipulatives, for example, enhance passage between physical and virtual representations. It therefore provides a transition between stages in the reasoning process. In social modes of learning, physical manipulatives provide assistance in all social modes. Computer supported collaborative learning is provided in the physical presence of learners manipulating on the same tabletop device.

\section{TABLETOP USER INTERFACES WITH TANGIBLE AND TOUCH INTERACTION}

Technology has a fundamental role in learning. Multimedia technology and ICT are pervasive in our lives and children use technology daily. Use of multimedia and ICT at an early stage and gaining relevant competences are necessities for today's careers.

Not only do personal computers, tablets and mobile devices represent the technology used in learning, classroom learning incorporates different traditional teaching aids for learning mathematics, chemistry, geography, etc. With technological advances, many traditional teaching aids acquire embedded technology (e.g. electronic circuits, sensors and buttons) or virtual representations (e.g. computer activities).

Hand manipulation in the physical world enables learners to interact with the digital environment and the keyboard and mouse still constitute the prevalent computer 
interface. There are two fundamental actions associated with a mouse: point $\&$ click and drag $\&$ drop [3-5].

With the recent wide-spread adoption of tablet computers, touch-based interaction is becoming an important aspect of the user interface. Its positive acceptance by users, together with the high technological achievement of recent tablet computers, has resulted in wide spread use of tablets in classrooms worldwide. Multitouch systems, such as those offered by tablet computers, offer several advantages by providing more dynamic content and control capabilities, while at the same time enabling users to use their fingers. As tablet use has increased, tabletop learning environment touch technology has also entered learning, with large multi-touch screens enabling collaborative learning on a single device [6].

The introduction of GUIs requires alternative humancomputer interactions [7]. The rich digital world invites users to reach in, and another form of user interaction with the computing systems emerged around two decades ago, one that utilizes human ability to manipulate physical objects - the so-called tangible interaction or tangible user interface (TUI). Nevertheless, this approach has not entered the educational main stream although recent extensive publications prove its importance in the history of learning technologies.

Tangible interaction allows the utilization of users' motor skills for manipulating digital content. Using both hands to interact with the computer has motor and cognitive benefits in the learning process [2]. Children learn without being aware of it during play involving computer mediated direct physical manipulation of physical objects (physical representations). A TUI provides children with a process of exploration using a variety of objects and materials to support pupils' learning experience in achieving learning goals.

Tangible interaction is based on hand manipulation of physical objects, enabling users to interact with the digital world. Physical objects provide physical attributes [8], such as visual, tactile, and auditory attributes, as well as spatial properties, such as location, orientation and configuration.

Furthermore, tangible interaction explores other human senses, such as hearing and touch, to enhance users' experiences and learning. Interaction with computing systems using physical objects and hand manipulation to represent and control digital data has demonstrated great potential over the last two decades [2, 7].

How tangible interaction supports learning is explored through theories of learning and instruction and pedagogical practices deploying the design frameworks by:

- Support for physical interaction,

- $\quad$ Rich multimedia feedback,

- $\quad$ High-level of realism. [8]

Touch based interfaces offer dynamic content and control capabilities, where tangible systems offer several benefits by providing more accurate manipulation and faster learning of control actions. Recent attention has been devoted to hybrid tangible interfaces that combine tangible and classical (GUI) interfaces and offer teachers and learners the flexibility to use the most appropriate interaction style in a particular situation $[9,10]$. The proposed hybrid approach offers many possibilities and challenges for the future research. Tangible and touch can be also considered in a hybrid manner by enabling tangible interaction on a capacitive multi-touch display [11].

The idea of interaction with a computing system using physical objects to represent and control digital data has proved to be very powerful. It opens a natural way for children and students to interact with computer systems. In addition, it has been demonstrated that it can be used in wide variety of learning processes.

\section{CONCEPTUAL MODEL FOR LEARNING WITH INTERFACES}

Knowledge can be defined as the ability to give a proper response when confronted with a real world problem [12]. The response is a result of processes in the mind. In some cases, the response is information (i.e. spoken, written word); in others, a material activity (i.e. doing something).

\section{A. The meaning triangle}

The oldest model that relates the real world to our understanding of it and to the words and symbols we use to communicate about it is the Aristotle/Ogden meaning triangle $[13,14]$. Fig. 1. Things or objects (we shall call these " $O$ ") are items from the real world. Experiences in the psyche or concepts ("C") are ideas we hold about things in our minds. Words and other symbols ("S") are used to so that we can communicate about our thoughts denoting real world objects.

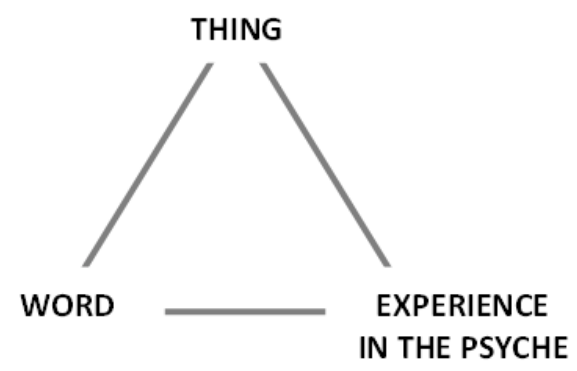

a)

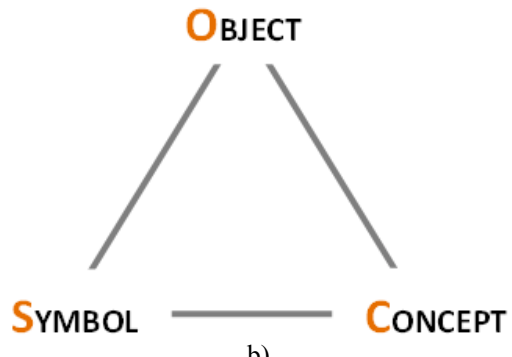

b)

Figure 1. The (semiotic) meaning triangles: a) Aristotle and Ogden, b) Richards.

In this context learning could be defined as equipping the student with useful "ideas in the psyche" so that real world situations can be understood and reacted to appropriately. Learning can happen in two ways - by "being in the world" (in the Heidegger's terms) and by learning what would happen if we interacted with the world. Learning while "being in the world" takes place with the interactions on the $\mathrm{C}-\mathrm{O}$ side of the triangle. In such a way, for example, a child learns that if you stop holding an object in mid-air it will fall down. Perhaps it will also break when it hits the ground. 
Another kind of learning takes place when we listen, view or read about models of the real world. Models are communicated to us using symbols, words, drawings, mathematical equations etc. In this way we may learn about Newton's law of mass and gravity. This kind of learning is happening along the C-S side of the triangle. We would remain on this side of the triangle even if we are looking at pictures of an apple tree and apples falling down from it while Isaac Newton is lying below it.

Our civilization mostly aims at teaching in a scientific way. The aim typically is not that a student will get a "feeling" of how fast things drop or at what load bridges collapse but to provide models and knowledge using which she or he could theoretically predict to a certain precision what the effect of some action would be. Evolutionally, for millions of years we have been used to learn on the C-O side of the triangle. No one explained things to us with pictures, models and theories. Only in the last couple of millennia have we become used to learning by listening to someone and in the last few hundred years we have learned by reading.

\section{B. Pedagogy in the meaning triangle}

Not surprisingly, the learning on the $\mathrm{C}-\mathrm{O}$ side is very efficient and a lot of effort in pedagogy has been dedicated to combining $\mathrm{C}-\mathrm{S}$ and $\mathrm{C}-\mathrm{O}$ kinds of learning or to make the C-S learning more closely resemble the $\mathrm{C}-\mathrm{O}$. If we analyse Bruner's [15] model of learning which includes enactive, iconic and symbolic levels, we see that combining different representational models is trying to build on human ability to learn naturally on the $\mathrm{C}-\mathrm{O}$ side.

Schools are full of tangible objects with which student experiment: in physics; doing chemistry tests; touching stuffed animals in biology. Even math is taught with bean calculators in the beginning. According to constructivism, learning undertakes the construction of mental models which explain to the learner what and how [16]. The move from objectivism to constructivism is underlined by the paradigm that knowledge is constructed and interpreted by the learner and is not an external object). The cognitivist view of research of cognitive processes and mental models highlights the role of cognitive tasks in learning. Bruner's [15] notion is of representations in learning which support learners' comprehension and its transition between the external representations and abstract conceptualisation.

The role of models and modelling is to support the scientific in pedagogical process when exploring real life (tangible or intangible), applying a variety of symbol systems. The model supports interaction between the real world and the learner's "psyche". The learning process, according to constructivist view, is based on the learner's engagement and active role when interacting with learning contents. The transmission of knowledge is replaced by construction of knowledge. The social context in the learning process and the notion of shared and/or distributed knowledge facilitates the recognition of the sociocultural environment in learning and the role of peers. Students are influenced by the context and social context makes an important contribution to their learning process [17]. In the process of construction of knowledge, the model is transferred from the "psyche" of individual learner to the shared space. In the learning process, this supports the individual learner's learning by explaining, exchanging, justifying with peers, and with those more experienced than themselves.

Understanding of teaching as transmission of information which supports simple forms of knowledge has moved towards the constructivist model of instruction, fostering construction of knowledge which facilitates a higher level of knowledge. (In Bloom's taxonomy this corresponds to the higher levels of application in new situations, evaluation and synthesis). Teaching and learning methods include inquiry learning, experimental learning, problem based learning, case studies, project work, simulations and games, hands-on laboratory exercises, and virtual laboratory activities . Computers support visualisation in learning and provide a more natural passage from problem visualization to problem analysis and forecasting solutions than do the paper and pen tasks which are usually required of students at the beginning a formal deduction [18].

Computer based dynamic modelling and dynamic visualization assist manipulation, and experimenting with models and simulations provides visual feedback. Casual relations are simulated with controlled and isolated variables in dynamic and simplified models. Simple and complex conceptual structures and processes can be presented gradually in a controlled setting. Following the constructivist teaching, computer modelling facilitates construction and reconstruction of knowledge and concepts, fostering qualitative understanding of science concepts. Conditions for setting a constructivist simulation based approach are contextual understanding and solving authentic problems for application of new knowledge. Learning based on representations can significantly improve concept understanding if structured to identify students' existing conceptions, thus facilitating them to think actively and set hypotheses prior to experimenting. Collaboration activity provides sharing with peers [17] when evaluating in progressing towards concept understanding. Complexity of dynamic visualisations requires planning of the learning process with a focus on specific variables and generation of hypotheses between variables prior to undertaking the experiment and following with evaluation and discussion of the results [19].

TUI merges the characteristics of hands-on learning in physical and virtual contexts and as such provides transfers between enactive, visual and symbolic levels of representations and modelling.

With the advent of computers there appeared a possibility to replace the real world with in-silico representations. Instead of tackling the real world items, learners would manipulate symbolic representations of these objects on screen. The cognitive distance between these objects and real world experiences would be much lower than between a mathematical representation of the problem and its real world occurrence.

In this article two models are applied for the study of TUI in learning and teaching, one focusing on stages in learning [15] and one focusing on learning outcomes [20]. Brunner designed a three stage model to explain how humans process information and understand the world through motor action, conventionalised imagery and perception and through language and reasoning. Bruner's three stage model of learning [15] has a first enactive stage in which the learner manipulates physical objects and material directly; a second - iconic - stage in which 
the learner interacts with images of objects and not directly with physical objects; and the third - symbolic - stage in which the learner no longer applies mental images or objects but instead uses symbol systems. Gagné's taxonomy of learning outcomes consists of psychomotor skills, verbal information, intellectual skills, cognitive strategies and attitudes [20].

\section{Hypothesis}

The hypothesis for the use of touch interfaces in user interface design is that the symbolic world of computers becomes much more similar to the real world. It makes it possible to get the learning effects and methodologies of learning on the $\mathrm{C}-\mathrm{O}$ axis by using the much cheaper, computer generated $\mathrm{C}-\mathrm{S}$ axis.

While almost any computer can display very realistic projections of the real world, specialised hardware and touch interfaces are needed to manipulate the projections with the same ease and lack of barriers as is the case when really manually manipulating the world.

We identified touch, hands and fingers as the most important interface for human beings to physically manipulate the physical world. The use of touch and fingers is therefore also the most important technology for manipulating computer generated symbolic representations of the real world and thus accumulating knowledge about it.

\section{LEARNING WITH TANGIBLE USER INTERFACES}

The beginnings of TUI research dates back to 1995 when [21] presented Graspable User Interfaces, later termed Tangible User Interfaces by [22]. In [23] proposed that the idea is to eliminate the distinctions between input and output device. After nearly two decades, tangible interaction is still relevant and follows the idea of combining digital information, physical object and environment.

Two handed manipulation enables users to utilize their natural ability to grasp and move physical objects as well as providing easy control of multiple parameters [7].

Children's ability to use any interfaces needs special attention due to their developing motor skills, limited reach, short attention spans, limited knowledge and experience with traditional user interfaces and social protocols [24].

Tangible interaction is based on tangible physical objects enabling users to interact with the digital world. Users interact by moving, manipulating, assembling and disassembling physical objects. Physical objects provide:

- Physical attributes: visual attributes, tactile attributes, and auditory attributes,

- Spatial properties: location, orientation and configuration [8]

External representations have an important role in mediating cognition [6]. Physical attributes provide instant information about shape and colour, for example. The use of different physical attributes provides information thorough multiple sensory channels. Multimodality of the tangible interaction and persistence of the physical world enables the use of different communication channels [7]. In the virtual (digital) domain, digital objects represent virtual entities with particular attributes. With tangible interaction, learners are required to establish meaningful mappings between artefacts and action [6].

Physical space is used for interaction, and exploits spatial reasoning skills [7]. Spatial TUI as tangible user inter- faces are used to mediate interaction in the virtual (digital) domain [25] and offer actions analogous to real-world effect or similar action [26]. Users' experience must help them to interpret spatial location and orientation of objects immediately and to suggest appropriate manipulation [7].

Integration of technologies differs between many systems introduced $[6,7]$. TUI systems can be classified into three main categories or levels of integration (Fig. 2):

1. Discrete

2. Collocated

3. Embedded

The three groups are organized based on input and output location.

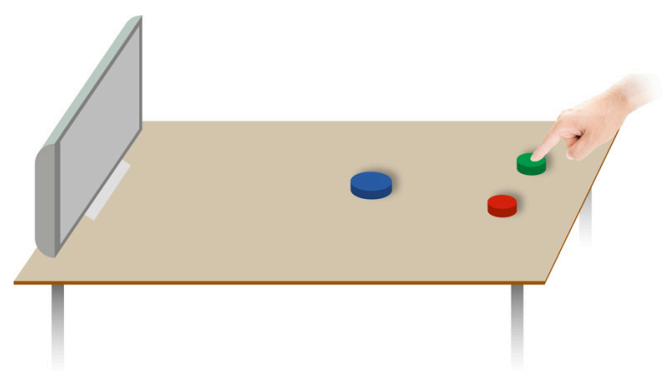

a)

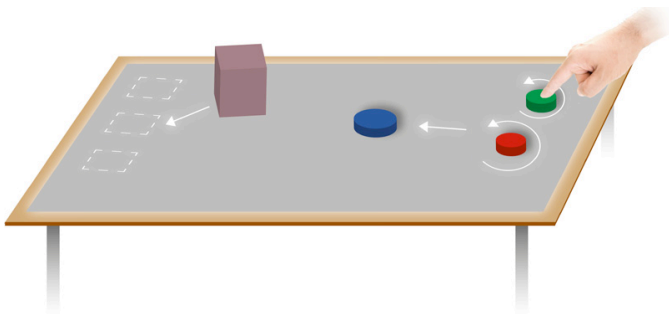

b)

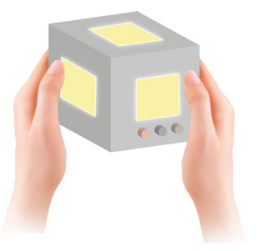

c)

Figure 2. Types of tangible interaction: a) Discrete, b) Collocated and c) Embedded [7]

The first and second categories share many similarities in the way physical manipulatives are placed on a surface such as a tabletop. In the first case, the output (display) is usually positioned vertically, e. g. a computer screen [18] or TV set [27].

In the second category, the output is collocated with the input usually resulting in display being part of the surface (e.g. large touch screens or projected surface). [28] use Thinker Lamp in vocational training, where a projector displays the output on the table top and a mounted camera above follows the action on the tabletop. Schneider et al, [29] evaluate BrainExplorer, allowing students to learn neuroscience by interacting with a tangible user interface where camera and Wiimote track the actively on the tabletop with a projector underneath displaying multimedia information. The project TagTiles, a game for training 
non-verbal cognitive skills, uses simple feedback by LED lights and audio output [30].

The third, embedded category, represents a tangible user interface where the system is embedded within the object, such as the use of physical objects augmented with sensors and LCD displays [31]. Interacting cubes with sensors and LCD displays were also introduced by SynFlo using Sifteo cubes [11], or other simple input/output switches, buttons and lights as in FlowBlock [32].

Differences between the discrete and collocated alternatives are on one hand technical in nature but also influence learning. As [33] reports, the two location modes have key implications for learning, where research shows that the discrete category gives users more time to think, while the collocated resulted in more dynamic access and collaboration. Collocated seems to better enable working in small groups and pairs.

Recent developments with touch and gesture interactions present tabletop computing devices as next generation education technology $[34,35]$.

\section{METhODS}

A systematic review of scientific articles applying qualitative and quantitative approaches was undertaken. All published articles in selected relevant journals and conference proceedings were included based on data collection in WOS and on a manual search in selected relevant journals and conference proceedings. The first stage of review was undertaken in the WOS database and in IEEE Explore, ACM Digital Library, Springer and Elsevier. The keywords used were: tangible interaction, tangible user interface and education or learning and/or computer supported learning. Based on the results from the first phase the conference articles were included from ACM digital library and journals for manual search were selected. The manual search was undertaken in the second phase. The journals were selected based on appearance of articles identified in the first phase. The journals were: Journal of Educational Technology and Society, Personal and Ubiquitous Computing, IEEE Transaction on Learning Technologies, International Journal of Human-Computer Studies, British Journal of Educational Technology, Computer Assisted learning. Criteria for inclusion of articles from ACM digital library and journals in the review was that article presents a pedagogical empirical research. The period covered was from 1995 to 2013. All articles were analysed based on reading full papers. The content analysis was conducted to examine pedagogical approaches based on the two models of Bruner [15] and Gagné [20] and presented in a Fig. 3. Articles are examined by subject, learners and level of education and objectives, modes and methods of teaching and learning (Table 1).

\section{FINDINGS AND DISCUSSION}

The manipulative properties of tangible user interfaces' physical manipulatives, for example, enhance passage between physical and virtual representations. In the reasoning process they therefore provide for the transition between reasoning stages and learning stages/levels (Bruner, 1966). In social modes of learning, physical manipulatives provide assistance in all social modes; individual, pairs, small groups and teacher up front. Computer supported collaborative learning is provided in the physi- cal presence of learners manipulating on the same tabletop device.

We use the socio-cultural theory of learning and instruction in our/the discussion of cognition and learning in this new environment. fied:

In the review process the following topics were identi-

- Cognitive processes and multiple representations assisted by tangible and touch interaction in learning.

- Social process and social modes and computer supported collaborative learning supported by tangible and touch interaction.

- Recognising diversity and individual differences, learners' needs and the potential of tangible and touch interaction in computer assisted learning. In contemporary society, inclusion of people with disabilities in the mainstream education is supported by use of novel interfaces.

\section{A. Socio-cultural theories of learning and instruction supporting novel teaching and learning approaches}

The socio-cultural paradigm is based on the notion of the human mind being connected to societal and cultural forms where reality is represented by symbolism that is distributed and shared. Meaning making is culturally situated and underlined by cultural symbol systems. Cultural resources for (for example ICT) influence cognition and learning. ICT transforms ways of knowledge construction and circulation in the society. The socio-cultural view of learning has two assumptions: (1) The learner co-creates and negotiates meaning and knowledge in the sociocultural context by the use of symbol systems [17]. (2) meaning making and learning is mediated by cultural resources or tools: physical and psychological, [17].

\section{B. Cognitive and social processes for diversity}

The reviewed articles were analysed based on Gagné's taxonomy of learning outcomes. Gagné holds that motor skills correspond to the psychomotor domain. Verbal information corresponds to the first two levels of Bloom's cognitive taxonomy: knowledge and comprehension [36]. Intellectual skills consist of: discrimination - differentiating and distinguishing between different contents and objects according to certain characteristics; concrete concepts - recognising and identifying classes of contents and objects; defined concepts - inserting new items using existing classification; rules and principles - applying relationship (casual) in thinking and problem solving; and higher order rules - applying complex rules to solve new problem or reasoning situations. Cognitive strategies consist of metacognition, creative thinking, critical thinking and innovation. Attitudes correspond to Bloom's affective learning outcomes [36].

In the Fig. 3 (Appendix) articles are presented based on the Gagné's taxonomy of learning outcomes and Bruner's three levels of learning. The Table 1 (Appendix) presents all analysed articles by subject, learners and level of education and objectives, modes and methods of teaching and learning.

Based on Gagne's taxonomy of learning outcomes, most articles were identified in intellectual skills and cognitive processing, few in psychomotor skills and one in verbal skills (Fig. 3). Articles examine cognition as situated in a social context. TUI supported collaborative learn- 
ing is recognised as essential for quality learning outcomes and is a focus of all articles under examination. Collaborative learning provides a natural learning context where knowledge is co-constructed and shared and socially negotiated [17]. The outcomes of the individual and the group are interrelated.

Cognition is socially situated and deploys representational systems combining different stages and the affordance of physical manipulation supporting tactile experience and virtual manipulation supporting visual experiences. The enactive level is that on which children's cognition is supported by motor action which can be whole body movement or fine motor movement [37-39]; vocational students learn logistics through bimanual manipulation while transferring from concrete action to symbol/ic level [28]; and medical students simulate surgery using bimanual manipulation and learn brain concepts while transferring from enactive experience to symbol/ic [40]. Iconic representations were applied by using TUI objects for manipulation [41], or virtual representations for tangible or intangible real life or hypothetical processes, solving real life problems. Both iconic representations are also applied in parallel [42]. A TUI can support bridging the gap between theory and practice $[28,40]$ or can facilitate learning and use of computer programming on the iconic level as, for example, when children in pre-school learn computer programming using objects and icons [42, 43] and using whole body movement [37]. The symbolic level is connected with intellectual skills and cognitive processing. The majority of reviewed articles combine all three levels of representations aiming at learning on a symbolic level for intellectual learning objectives and cognitive strategies (Fig. 3).

External representations facilitate cognition and learning. According to [6], spatial organisation of the learning environment with regard to location of physical and virtual representations affect mapping between artefacts and action. They have identified difficulties for children learning physics in transfering to symbolic representations [6]. The location influences the dynamics, and how transfers between the representation stages in which correspondence and modality influence mapping are undertaken. Whether the display is positioned vertically or horizontally influences collaborative work.[6] have identified the collocated working environment as productive for collaborative learning.

Articles presenting TUIs for the learning of learners with special needs support the inclusion of learners with special needs in collaborative learning because they benefit from social context [18, 27], facilitate cognitive development $[18,27]$, and it assists their needs and accessibility requirements for learning [41].

\section{CONCLUSION}

Tangible user interfaces are popular since first developments in mid 90' and still under investigation as demonstrated by the increased attention devoted to them in the scientific domain in the recent years. In this paper we followed the development from first technological investigations to recent classroom deployed systems influencing the pedagogical developments and commercial products used for play and learning.

Appropriate user interfaces can relax cognitive load and enable students to grasp mental and physical challenges.
In this article the cognitive and the social process were examined, presenting the affordance of TUIs in learning.

Desktop technology takes advantage of a classroom table which is a natural environment for learning activities, enabling group activity and collaboration. Because computing is ubiquitous, researchers are searching for new ways of accessing and interacting with computers for diverse user groups.

Tangible user interfaces support cognitive processes and concept modelling, assisted by multiple representation. The manipulative properties of physical objects enhance passage between physical and virtual representations, facilitating a transition between stages in the reasoning process. In social modes of learning, physical manipulatives provide assistance in all social modes applied on a single interface.

In the future adaptable interfaces will further improve students' learning experiences and further evolve ideas of collaboration and inclusion. Advanced technologies will enable new ways of learning systems and interactions of people and devices. These systems will better utilise human sensing to enhance the dialog with computers.

\section{REFERENCES}

[1] Computing education. IEEE Computer, 46 (9) 2013.

[2] Special Issue on Tangible Interaction and Children. Personal and Ubiquitous Computing, ISSN: 1617-4917 (Online), 16 (4), 2012.

[3] Inkpen, K. M. Drag-and-drop versus point-and-click mouse interaction styles for children. ACM Transactions on ComputerHuman Interaction, 8 (11), 1-33, 2001. http://dx.doi.org/10.1145/ $\underline{371127.371146}$

[4] Fitzmaurice, G. W. \& Buxton, W. An empirical evaluation of graspable user interfaces: towards specialized, space-multiplexed input. In S. Pemberton (Ed.), Proceedings of the SIGCHI Conference on Human Factors in Computing Systems, March 22-27, 43 50, 1997. http://dx.doi.org/10.1145/258549.258578

[5] Tuddenham, P. Graspables revisited: multi-touch vs. tangible input for desktop displays in acquisition and manipulation tasks. In A. Sarcevic (Ed.), Proceedings of the 28th International Conference on Human Factors in Computing Systems, 2223-2232, 2010. http://dx.doi.org/10.1145/1753326.1753662

[6] Price, S., \& Rogers, Y. Let's get physical: the learning benefits of interacting in digitally augmented physical spaces. Computers \& Education, 43 (1), 137-151, 2004. http://dx.doi.org/10.1016/ j.compedu.2003.12.009

[7] Van den Hoven, E., van de Garde-Perik, E., Offermans, S., van Boerdonk, K., \& Lenssen, K. M. H. Moving tangible interaction systems to the next level. Computer, 46 (8), 70-76, 2013. http://dx.doi.org/10.1109/MC.2012.360

[8] Antle, A. N., \& Wise, A. F. Getting down to details: Using theories of cognition and learning to inform tangible user interface design. Interacting with Computers, 25 (1), 1-20, 2013.

[9] Horn, M. S., Crouser, R. J., \& Bers, M. U.. Tangible interaction and learning: The case for a hybrid approach. Personal and Ubiq$\begin{array}{lllll}\text { uitous } & \text { Computing, } 16 & \text { (4), 379-389, } 2012 .\end{array}$ http://dx.doi.org/10.1007/s00779-011-0404-2

[10] Fjeld, M., Fredriksson, J., Ejdestig, M., Duca, F., Bötschi, K., Voegtli, B., \& Juchli, P. Tangible user interface for chemistry education: comparative evaluation and re-design. In Proceedings of the SIGCHI conference on Human factors in computing systems (pp. 805-808). ACM, 2007. http://dx.doi.org/10.1145/1240624. 1240745

[11] Shaer, O., Valdes, C., Liu, S., Lu, K., Chang, K., Xu, W., Haddock T. L., Bhatia, S., Desmore, D. \& Kincaid, R. Designing reality-based interfaces for experiential bio-design. Personal and Ubiquitous Computing, 1-18, 2013.

[12] Winograd, T. Thinking machines: Can there be? Are we? in James Sheehan and Morton Sosna, eds., The Boundaries of Humanity: 
Humans, Animals, Machines, Berkeley: University of California Press, pp. 198-223, 1991.

[13] Falcon, A. Aristotle on Causality. Stanford Encyclopedia of Philosophy 2008.

[14] Ogden C. K. \& Richards I. A. The Meaning of Meaning. In: Gordon W. T. (ed.) C. K. Ogden and Linguistics, Routledge/Thoemmes Press, London, 1994, ISBN 0415103533, (first published: 1923).

[15] Bruner, J. S. Toward a theory of instruction. Cambridge, MA: Harvard University Press., 1966.

[16] Jonassen, D. H. Objectivism versus constructivism: do we need an new psychological paradigm? Educational technology research $\begin{array}{llll}\text { and development, } 39 & \text { (3), } & 5-14, & 1991 .\end{array}$ http://dx.doi.org/10.1007/BF02296434

[17] Vygotsky, L. S. Mind in society: The development of higher psychological processes. Cambridge, MA: Harvard University Press., 1978.

[18] Starcic, A. I., Cotic, M., \& Zajc, M. Design-based research on the use of a tangible user interface for geometry teaching in an inclusive classroom. British Journal of Educational Technology, 44(5), 729-744., 2013. http://dx.doi.org/10.1111/j.1467-8535.2012.013 41.x

[19] Bodemer, D., Ploetzner, R., Feuerlein, I., Spada, H. The active integration of information during learning with dynamic and interactive visualisations, Learning and Instruction, 14 (3) 325-341, 2004. http://dx.doi.org/10.1016/j.learninstruc.2004.06.006

[20] Gagné, R. M. The conditions of learning. New York: Richard \& Winston., 1985.

[21] Fitzmaurice, G. W., Ishii, H., \& Buxton, W. A. Bricks: laying the foundations for graspable user interfaces. In Proceedings of the SIGCHI conference on Human factors in computing systems (pp. 442-449). ACM Press/Addison-Wesley Publishing Co., 1995. http://dx.doi.org/10.1145/223904.223964

[22] Ishii, H., \& Ullmer, B. Tangible bits: towards seamless interfaces between people, bits and atoms. In Proceedings of the ACM SIGCHI Conference on Human factors in computing systems (pp. 234-241). ACM, 1997. http://dx.doi.org/10.1145/258549.258715

[23] Ullmer, B., \& Ishii, H. Emerging frameworks for tangible user interfaces. in Human-Computer Interaction in the New Millenium, (J. M. Carroll, ed.), pp. 579-601, Addison-Wesley, 2001

[24] Rounding, K., Tee, K., Wu, X., Guo, C., \& Tse, E. Evaluating interfaces with children. Personal and ubiquitous computing, 17 (8), 1663-1666, 2013. http://dx.doi.org/10.1007/s00779-012-05216

[25] Sharlin, E., Watson, B., Sutphen, S., Liu, L., Lederer, R., \& Frazer, J. A tangible user interface for assessing cognitive mapping ability. International Journal of Human-Computer Studies, 67 (3), 269-278, 2009. http://dx.doi.org/10.1016/j.ijhcs.2008.09.014

[26] Fishkin, K. A taxonomy for and analysis of tangible interfaces. Personal and Ubiquitous Computing, 8, 5, 347-358, 2004. http://dx.doi.org/10.1007/s00779-004-0297-4

[27] Marco, J., Cerezo, E., Baldassarri, S., Mazzone, E., \& Read, J. C. Bringing tabletop technologies to kindergarten children. In Proceedings of the 23rd British HCI Group Annual Conference on People and Computers: Celebrating People and Technology (pp. 103-111). British Computer Society, 2009.

[28] Schneider, B., Jermann, P., Zufferey, G., \& Dillenbourg, P. Benefits of a tangible interface for collaborative learning and interaction. Learning Technologies, IEEE Transactions on, 4 (3), 222232, 2011

[29] Schneider, B.; Wallace, J.; Blikstein, P.; Pea, R. Preparing for Future Learning with a Tangible User Interface: The Case of Neuroscience. Learning Technologies, IEEE Transactions on, vol.6, no.2, 117,129, 2013.

[30] Verhaegh, J., Fontijn, W. F., Aarts, E. H., \& Resing, W. C. Ingame assessment and training of nonverbal cognitive skills using TagTiles. Personal and ubiquitous computing, 17(8), 1637-1646, 2013. http://dx.doi.org/10.1007/s00779-012-0527-0

[31] Terrenghi, L., Kranz, M., Holleis, P., \& Schmidt, A. A cube to learn: a tangible user interface for the design of a learning appliance. Personal and Ubiquitous Computing, 10(2-3), 153-158, 2006. http://dx.doi.org/10.1007/s00779-005-0025-8
[32] Zuckerman, O., \& Gal-Oz, A. To TUI or not to TUI: Evaluating performance and preference in tangible vs. graphical user interfaces. International Journal of Human-Computer Studies, 71(7), 803820, 2013. http://dx.doi.org/10.1016/j.ijhcs.2013.04.003

[33] Rogers, Y., \& Lindley, S. Collaborating around vertical and horizontal large interactive displays: which way is best? Interacting with Computers, 16(6), 1133-1152, 2004. http://dx.doi.org/10.1016/j.intcom.2004.07.008

[34] Anthony, L., Brown, Q., Tate, B., Nias, J., Brewer, R., \& Irwin, G. Designing smarter touch-based interfaces for educational contexts. Personal and Ubiquitous Computing, 1-13, 2013.

[35] Zajc, M., \& Starcic, A. I. (2012). Potentials of the tangible user interface (TUI) in enhancing inclusion of people with special needs in the ICT-Assisted learning and e-accessibility. In Agent and Multi-Agent Systems. Technologies and Applications, 261270. Springer Berlin Heidelberg.

[36] Bloom, B. Taxonomy of Educational Objectives, Handbook I: The Cognitive Domain. New York: David McKay, 1956.

[37] Fernaeus, Y., \& Tholander, J. "Looking At the Computer but Doing It On Land": Children's Interactions in a Tangible Programming Space. In People and Computers XIX-The Bigger Picture (pp. 3-18). Springer London, 2006.

[38] Zaman, B., \& Abeele, V. V. How to measure the likeability of tangible interaction with preschoolers. Proc. CHI Nederland, 5, 2007.

[39] Faber, J. P., \& Van Den Hoven, E. MARBOWL: increasing the fun experience of shooting marbles. Personal and Ubiquitous Computing, 16 (4), 391-404, 2012. http://dx.doi.org/10.1007/ s00779-011-0405-1

[40] Hinckley, K., Pausch, R., Goble, J. C., \& Kassell, N. F. (1994). Passive real-world interface props for neurosurgical visualization. In Proceedings of the SIGCHI conference on Human factors in computing systems (pp. 452-458). ACM.

[41] Sitdhisanguan, K., Chotikakamthorn, N., Dechaboon, A., \& Out, P. Using tangible user interfaces in computer-based training systems for low-functioning autistic children. Personal and Ubiquitous Computing, 16(2), 143-155, 2012. http://dx.doi.org/10.1007/ s00779-011-0382-4

[42] Horn, M. S., \& Jacob, R. J. Designing tangible programming languages for classroom use. In Proceedings of the 1st international conference on Tangible and embedded interaction (pp. 159162). ACM, 2007. http://dx.doi.org/10.1145/1226969.1227003

[43] Sapounidis, T., \& Demetriadis, S. Tangible versus graphical user interfaces for robot programming: exploring cross-age children's preferences. Personal and ubiquitous computing, 17(8), 17751786, 2013. http://dx.doi.org/10.1007/s00779-013-0641-7

[44] Africano, D., Berg, S., Lindbergh, K., Lundholm, P., Nilbrink, F., \& Persson, A. Designing tangible interfaces for children's collaboration. In $\mathrm{CHI}^{\prime} 04$ extended abstracts on Human factors in computing systems (pp. 853-868). ACM, 2004. http://dx.doi.org/10.1145/ 985921.985945

[45] Price, S., Falcão, T. P., Sheridan, J. G., \& Roussos, G. The effect of representation location on interaction in a tangible learning environment. In Proceedings of the 3rd International Conference on Tangible and Embedded Interaction (pp. 85-92). ACM, 2009. http://dx.doi.org/10.1145/1517664.1517689

[46] Lackner, T. M., Dobson, K., Rodenstein, R., \& Weisman, L. Sensory puzzles. In CHI'99 Extended Abstracts on Human Factors in Computing Systems (pp. 270-271). ACM, 1999. http://dx.doi.org/10.1145/632716.632882

[47] Ryokai, K., \& Cassell, J. StoryMat: a play space for collaborative storytelling. In CHI'99 Extended Abstracts on Human Factors in Computing Systems (pp. 272-273). ACM, 1999.

[48] Scarlatos, L. L., Dushkina, Y., \& Landy, S. TICLE: a tangible interface for collaborative learning environments. In CHI'99 Extended Abstracts on Human Factors in Computing Systems (pp. 260-261). ACM, 1999. http://dx.doi.org/10.1145/632716.632876

[49] Jackson, A. T., Brummel, B. J., Pollet, C. L., \& Greer, D. D. An evaluation of interactive tabletops in elementary mathematics education. Educational Technology Research and Development, 61(2), 311-332, 2013. http://dx.doi.org/10.1007/s11423-013-9287- 
[50] Starcic, A. I., \& Zajc, M. An interactive tangible user interface application for learning addition concepts. British Journal of Educational Technology, 42(6), E131-E135, 2011. http://dx.doi.org/10.1111/j.1467-8535.2011.01217.x

[51] Fails, J. A., Druin, A., Guha, M. L., Chipman, G., Simms, S., \& Churaman, W. Child's play: a comparison of desktop and physical interactive environments. In Proceedings of the 2005 conference on Interaction design and children (pp. 48-55). ACM, 2005. http://dx.doi.org/10.1145/1109540.1109547

[52] Sylla, C., Branco, P., Coutinho, C., \& Coquet, M. E. Storytelling through drawings: evaluating tangible interfaces for children. In CHI'09 Extended Abstracts on Human Factors in Computing Systems (pp. 3461-3466). ACM, 2009.

[53] Sylla, C., Branco, P., Coutinho, C., \& Coquet, E. TUIs vs. GUIs: comparing the learning potential with preschoolers. Personal and Ubiquitous Computing, 16(4), 421-432, 2012.Frei, P., Su, V., Mikhak, B., \& Ishii, H. Curlybot: designing a new class of computational toys. In Proceedings of the SIGCHI conference on Human factors in computing systems (pp. 129-136). ACM, 2000.

[54] Girouard, A., Solovey, E. T., Hirshfield, L. M., Ecott, S., Shaer, O., \& Jacob, R. J. Smart Blocks: a tangible mathematical manipulative. In Proceedings of the 1 st international conference on Tangible and embedded interaction (pp. 183-186). ACM, 2007. http://dx.doi.org/10.1145/1226969.1227007

[55] Greenberg, S., \& Fitchett, C. Phidgets: easy development of physical interfaces through physical widgets. In Proceedings of the 14th annual ACM symposium on User interface software and technology (pp. 209-218). ACM, 2001. http://dx.doi.org/10.1145/502348.502388

[56] Huang, C. J., Yi-Luen Do, E., \& Gross, (MouseHaus Table: a Physical Interface for Urban Design. In 16th Annual ACM Symposium on User Interface Software and Technology (UIST). 2003.

[57] Raffle, H. S., Parkes, A. J., \& Ishii, H. Topobo: a constructive assembly system with kinetic memory. In Proceedings of the SIGCHI conference on Human factors in computing systems (pp. 647-654). ACM, 2004. http://dx.doi.org/10.1145/985692.985774

[58] Wyeth, P., \& Wyeth, G. Electronic blocks: Tangible programming elements for preschoolers. In Proceedings of the Eighth IFIP TC13 Conference on Human-Computer Interaction (pp. 496-503). Amsterdam: IOS Press., 2001.

[59] Marshall, P., Fleck, R., Harris, A., Rick, J., Hornecker, E., Rogers, Y., Yuill, N. \& Dalton, N. S. Fighting for control: children's embodied interactions when using physical and digital representations. In Proceedings of the SIGCHI Conference on Human Factors in Computing Systems (pp. 2149-2152). ACM, 2009. http://dx.doi.org/10.1145/1518701.1519027

[60] Resnick, M., Martin, F., Berg, R., Borovoy, R., Colella, V., Kramer, K., \& Silverman, B. Digital manipulatives: new toys to think with. In Proceedings of the SIGCHI conference on Human factors in computing systems (pp. 281-287). ACM Press/Addison-Wesley Publishing Co., 1998. http://dx.doi.org/10.1145/274644.274684

[61] Stanton, D., Bayon, V., Neale, H., Ghali, A., Benford, S., Cobb, S., \& Pridmore, T. Classroom collaboration in the design of tangible interfaces for storytelling. In Proceedings of the SIGCHI conference on Human factors in computing systems (pp. 482-489). ACM, 2001. http://dx.doi.org/10.1145/365024.365322

[62] Chipman, G., Druin, A., Beer, D., Fails, J. A., Guha, M. L., \& Simms, S. A case study of tangible flags: a collaborative technology to enhance field trips. In Proceedings of the 2006 conference on Interaction design and children (pp. 1-8). ACM, 2006. http://dx.doi.org/10.1145/1139073.1139081

[63] Marshall, P., Cheng, P. C. H., \& Luckin, R. Tangibles in the balance: a discovery learning task with physical or graphical mate- rials. In Proceedings of the fourth international conference on Tangible, embedded, and embodied interaction (pp. 153-160). ACM, 2010. http://dx.doi.org/10.1145/1709886.1709914

[64] Bakker, S., Antle, A. N., \& Van Den Hoven, E. Embodied metaphors in tangible interaction design. Personal and Ubiquitous Computing, 16(4), 433-449, 2012. http://dx.doi.org/10.1007/ s00779-011-0410-4

\section{AUTHORS}

A. Istenič Starčič is with the Faculty of Civil and Geodetic Engineering, University of Ljubljana, Ljubljana, Faculty of Education and University of Primorska, Koper, Slovenia. She is a honorary fellow with Macquarie University Sydney, NSW, Australia (e-mail: andreja.starcic@gmail.com).

Dr. Andreja Istenič Starčič is an associate professor. Her teaching and research include Educational technology, Media and communication, Usability, Innovative user interface concepts supporting diverse user groups, Cognitive, social, affective aspects of human interactions with ICT. Andreja is Corresponding Editor in BJET - British Journal of Educational technology for Europe and Scandinavia. Andreja's website has details of her activities and publications: http://andreja-istenic-starcic.eu/.

Ž. Turk, is with the Faculty of Civil and Geodetic Engineering, University of Ljubljana, Ljubljana, Slovenia (email: ziga.turk@gmail.com).

Dr. Žiga Turk is a professor of construction information technology at the University of Ljubljana, Slovenia. His teaching and research include design communication and information modeling in architecture, engineering and construction as well as knowledge transfer, responsible research and innovation, internet science and the interplay between science and technology in global societal trends. He leads research program eConstruction

M. Zajc is with the Faculty of Electrical Engineering University of Ljubljana, Ljubljana, Slovenia (e-mail: matej.zajc@fe.uni-lj.si).

Dr. Matej Zajc is an associate professor at Information Communication Technologies Department. His research interests include interactive multimedia systems and services, human-computer interaction, tangible interaction, technology enhanced learning and applications of ambient intelligence. He teaches undergraduate and graduate courses in the fields of ICT and multimedia. In Spring 2015 he was visiting professor at University of Washington, Human Centered Design and Engineering Department.

This work was supported in part by the research program ARRS P2-0210 and ARRS P2-0246. Manuscript received 16 July 2015. Published as resubmitted by the author 15 November 2015 .

\section{APPENDIX}

See next pages. 
PAPER

Transforming Pedagogical Approaches Using TangIBle User InTERFACE EnABled Computer Assisted...

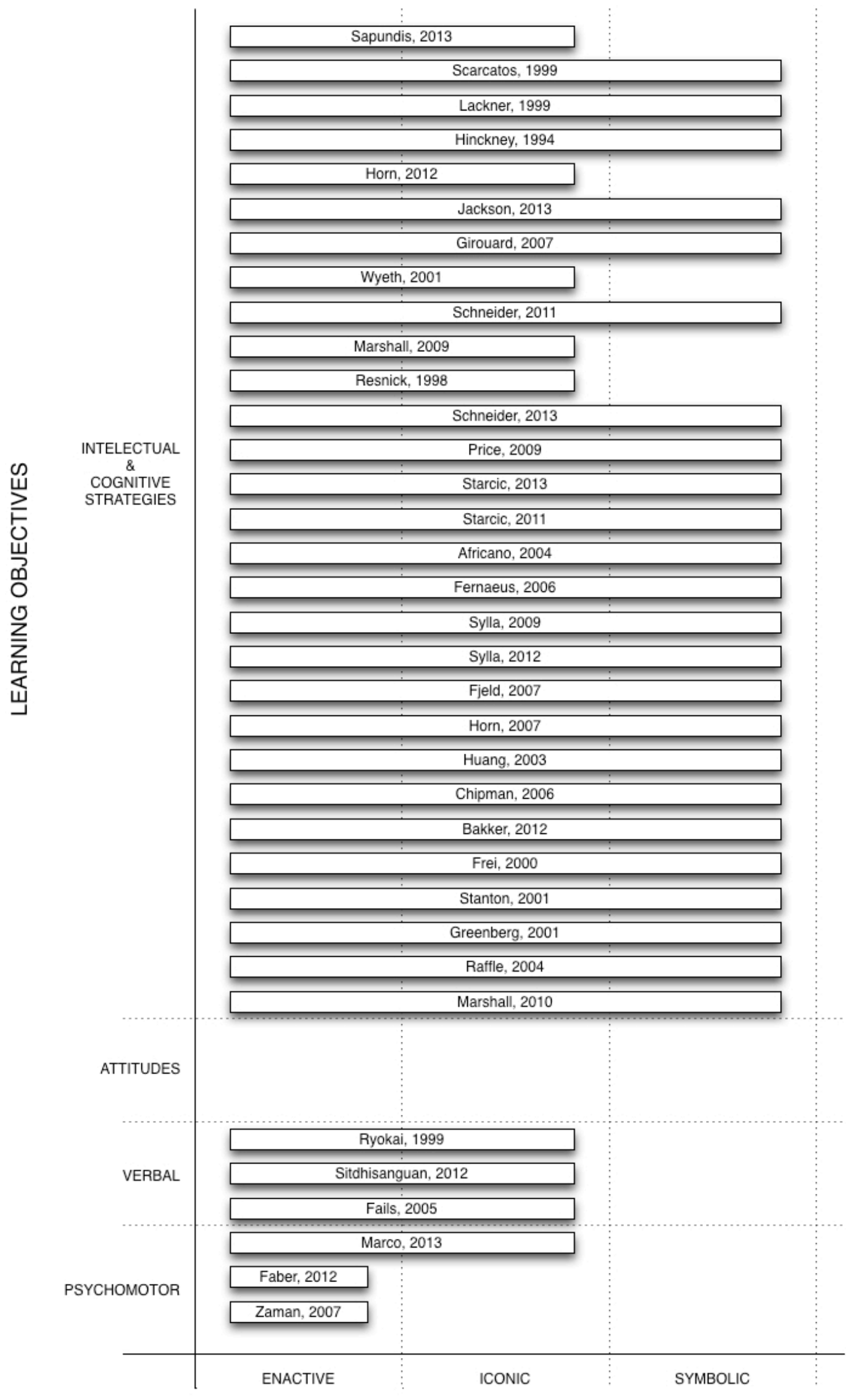

LEVELS OF LEARNING

Figure 3. Articles based on the Gagné's taxonomy of learning outcomes and Bruner's three levels of learning 
TABLE I.

ARTICLES BY SUBJECT, LEVEL OF EDUCATION, OBJECTIVES AND METHODS

\begin{tabular}{|c|c|c|c|c|}
\hline & Authors and year of publication & Subject & Learners and level & $\begin{array}{c}\text { Objectives, modes and methods of teaching } \\
\text { and learning }\end{array}$ \\
\hline 1 & $\begin{array}{l}\text { Africano, Lunholm, Berg, Nil- } \\
\text { brink, Lindbergh, Persson, } 2004 \\
{[44]}\end{array}$ & $\begin{array}{l}\text { Reading, writing, mathematics, } \\
\text { collaborative play }\end{array}$ & $\begin{array}{l}\text { Preschool } \\
\text { 1st grade primary } \\
\text { school }\end{array}$ & Basic literacies \\
\hline 2 & $\begin{array}{l}\text { Price, Falcao, Sheridan, Roussos, } \\
2009[45]\end{array}$ & Physics & Children aged 11 & $\begin{array}{l}\text { Learning physical concepts by collocated, } \\
\text { embodied and discrete tangible interaction }\end{array}$ \\
\hline 3 & $\begin{array}{l}\text { Hinckley, Pausch, Goble, Kasell, } \\
1994[40]\end{array}$ & Neurosurgery & & $\begin{array}{l}\text { Conceptual and procedural knowledge } \\
\text { 3D visualisation and manipulative skills in } \\
\text { surgery }\end{array}$ \\
\hline 4 & $\begin{array}{l}\text { Lackner, Dobson, Rodenstein, } \\
\text { Weisman, } 1999 \text { [46] }\end{array}$ & Music & $\begin{array}{l}\text { Children and adults } \\
\text { with different sensory } \\
\text { abilities (visual impair- } \\
\text { ment) }\end{array}$ & $\begin{array}{l}\text { Collaborative construction of music; Multi- } \\
\text { modal construction with the sensory puzzle } \\
\text { (auditory and tactile feedback) for learning } \\
\text { music theory }\end{array}$ \\
\hline 5 & Ryokai, Casell, 1999 [47] & Language and literature & & $\begin{array}{l}\text { Narrative play: Collaborative storytelling } \\
\text { activities }\end{array}$ \\
\hline 6 & $\begin{array}{l}\text { Scarlatos, Dushkina, Landy, } 1999 \\
\text { [48] }\end{array}$ & Mathematics; geometry & $\begin{array}{l}\text { Middle-school aged } \\
\text { children with difficul- } \\
\text { ties in mathematics }\end{array}$ & Geometric puzzle and collaboration \\
\hline 7 & Faber, Hoven, 2012 [39] & Social gaming & Secondary school & $\begin{array}{l}\text { Social marble gaming by TUI in open play- } \\
\text { ground supporting physical movement }\end{array}$ \\
\hline 8 & Horn, Crouser, Bers, 2012 [42] & $\begin{array}{l}\text { Computer programming language } \\
\text { Robotics }\end{array}$ & $\begin{array}{l}\text { Pre-school aged 5-6 } \\
\text { Children aged up to } 16\end{array}$ & $\begin{array}{l}\text { Comparing tangible and graphical TUI in } \\
\text { learning computer programming language and } \\
\text { robotics concepts }\end{array}$ \\
\hline 9 & $\begin{array}{l}\text { Jackson, Brummel, Pollet, Greer, } \\
2013 \text { [49] }\end{array}$ & Mathematics & $\begin{array}{l}\text { Fourth grade primary } \\
\text { school students }\end{array}$ & $\begin{array}{l}\text { Computer supported collaborative learning; } \\
\text { game based learning }\end{array}$ \\
\hline 10 & $\begin{array}{l}\text { Marco, Cerezo, Baldassarri, } \\
\text { Mazzone, Read, } 2013 \text { [27] }\end{array}$ & $\begin{array}{l}\text { Social skills and psychomotor } \\
\text { skills in computer gaming }\end{array}$ & $\begin{array}{l}\text { Pre-school children and } \\
\text { children with cognitive } \\
\text { disability aged } 7-11\end{array}$ & $\begin{array}{l}\text { Development of cognitive and psychomotor } \\
\text { skills; learning by physical activity, collabora- } \\
\text { tion and computer game }\end{array}$ \\
\hline 11 & $\begin{array}{l}\text { Sapounidis, Demetriadis, } 2013 \\
\text { [43] }\end{array}$ & Robot programming & Pre-school & $\begin{array}{l}\text { Comparing learning by physical manipulation } \\
\text { of TUI and iconic representations of graphical } \\
\text { interface }\end{array}$ \\
\hline 12 & $\begin{array}{l}\text { Schneider, Jermann, Zufferey, } \\
\text { Dilenbourg, } 2011 \text { [28] }\end{array}$ & Logistics & Vocational education & $\begin{array}{l}\text { Learning to apply theoretical knowledge in } \\
\text { practice }\end{array}$ \\
\hline 13 & $\begin{array}{l}\text { Schneider, Wallace, Blikstein, } \\
\text { Pea, 2013 [29] }\end{array}$ & Neuroscience & University education & $\begin{array}{l}\text { Active learning methods vs. Transmissive } \\
\text { learning in traditional classroom and from a } \\
\text { textbook }\end{array}$ \\
\hline 14 & $\begin{array}{l}\text { Sitdhisanguan; Chotikakamthorn, } \\
\text { Dechaboon, Out, } 2012 \text { [41] }\end{array}$ & $\begin{array}{l}\text { Basic skills of recognising shapes } \\
\text { and colour }\end{array}$ & $\begin{array}{l}\text { Pre-school autistic } \\
\text { children age } 3-5\end{array}$ & $\begin{array}{l}\text { Children with low motor skills using TUI; } \\
\text { transition from concrete to symbolic abstract } \\
\text { understanding }\end{array}$ \\
\hline 15 & Starcic, Cotic, Zajc, 2013 [18] & Mathematics; geometry & $\begin{array}{l}\text { Pre- primary school and } \\
\text { first three grades of } \\
\text { primary school includ- } \\
\text { ing students with learn- } \\
\text { ing difficulties and low } \\
\text { fine motor skills }\end{array}$ & $\begin{array}{l}\text { Developing geometry concepts combining } \\
\text { physical and cognitive activity; Transitions } \\
\text { through stages of geometry reasoning }\end{array}$ \\
\hline 16 & Starcic, Zajc, 2011 [50] & Mathematic; addition concepts & Primary school & $\begin{array}{l}\text { Learning addition concepts on the interactive } \\
\text { bale by tangibles }\end{array}$ \\
\hline 17 & $\begin{array}{l}\text { Fails, Druin, Guha, Chipman, } \\
\text { Simms, Churaman, } 2005 \text { [51] }\end{array}$ & $\begin{array}{l}\text { Environmental education, lan- } \\
\text { guage learning }\end{array}$ & Pre-school age 4-6 & $\begin{array}{l}\text { Discovery learning, creative story narrative, } \\
\text { game based learning with comparison of } \\
\text { desktop and physical environment with } \\
\text { integrated interactive technology in learning }\end{array}$ \\
\hline 18 & $\begin{array}{l}\text { Sylla, Branco, Coutinho, Coquet, } \\
2012[52]\end{array}$ & Health education, oral hygiene & Pre-school & $\begin{array}{l}\text { Manual skills for tooth brushing, understand- } \\
\text { ing of role of tooth brushing }\end{array}$ \\
\hline 19 & $\begin{array}{l}\text { Sylla, Coquet, Branco, Coutinho, } \\
2009[53]\end{array}$ & Health education, oral hygiene & Pre-school & Storytelling, drawing \\
\hline 20 & Zaman, Abeele, 2007 [38] & Play & Pre-school & $\begin{array}{l}\text { Psychomotor skills and motivation for game } \\
\text { based learning with TUI vs. keyboard }\end{array}$ \\
\hline 21 & \begin{tabular}{|l} 
Fjeld, Fredriksoon, Ejdestig, Duca, \\
Botschi, Voegtli, Juchli, 2007 [10]
\end{tabular} & Chemistry, organic chemistry & & $\begin{array}{l}\text { Learning abstract concepts by TUI based } \\
\text { manipulation with 3D molecular models }\end{array}$ \\
\hline 22 & Frei, Su, Mikhak, Ishii, 2000 [54] & Mathematics and Computing & Primary school & $\begin{array}{l}\text { Abstract concepts learning by TUI supporting } \\
\text { various learning styles }\end{array}$ \\
\hline
\end{tabular}


PAPER

Transforming Pedagogical ApProaches Using TANgible User InTERFACE EnABled Computer AsSisted...

\begin{tabular}{|c|c|c|c|c|}
\hline 23 & $\begin{array}{l}\text { Girouard, Treacy, Hirshfield, } \\
\text { Ecott, Shaer, Jacob, } 2007 \text { [55] }\end{array}$ & Mathematics & $\begin{array}{l}\text { Primary school age } 5- \\
12\end{array}$ & $\begin{array}{l}\text { Spatial concepts by 3D objects supporting } \\
\text { physical manipulation }\end{array}$ \\
\hline 24 & Greenberg, Fichett, 2001 [56] & Computing & University education & Developing physical interfaces \\
\hline 25 & Horn, Jacob, 2007 [42] & $\begin{array}{l}\text { Computer programming and } \\
\text { robotics }\end{array}$ & Primary school & $\begin{array}{l}\text { Independent program building by physical } \\
\text { manipulatives }\end{array}$ \\
\hline 26 & Huang, Do, Gross, 2003 [57] & Urban design & University education & $\begin{array}{l}\text { Participatory urban design with local commu- } \\
\text { nity applying TUI }\end{array}$ \\
\hline 27 & Raffle, Parkes, Ishii, 2004 [58] & Robotics & $\begin{array}{l}\text { Pre-school children, } \\
\text { primary school children } \\
\text { age } 5-13\end{array}$ & $\begin{array}{l}\text { Manipulating robotic models for pre-school } \\
\text { children; } \\
\text { Conceptual abstraction in robotics concepts } \\
\text { and design }\end{array}$ \\
\hline 28 & Wyeth, Wyeth, 2001 [59] & $\begin{array}{l}\text { Early childhood technology } \\
\text { education, } \\
\text { Computer programming }\end{array}$ & Pre-school & $\begin{array}{l}\text { Levels of knowledge: using TUIs, under- } \\
\text { standing them and program with them }\end{array}$ \\
\hline 29 & $\begin{array}{l}\text { Marshall, Fleck, Harris, Rick, } \\
\text { Hornecker, Rogers, Yuill, Dalton, } \\
2009 \text { [60] }\end{array}$ & $\begin{array}{l}\text { Social skills, psychomotor skills } \\
\text { using TUI }\end{array}$ & Primary school & $\begin{array}{l}\text { Collaboration and group dynamics using } \\
\text { physical and digital representations on a } \\
\text { tabletop }\end{array}$ \\
\hline 30 & $\begin{array}{l}\text { Resnick, Martin, Berg, Borovoy, } \\
\text { Colella, Kramer, Silverman, } 1998 \\
{[61]}\end{array}$ & Mathematics and science concepts & $\begin{array}{l}\text { Pre-school. Primary } \\
\text { school }\end{array}$ & $\begin{array}{l}\text { Digital and physical manipulatives in concept } \\
\text { learning (lego, breads, balls) }\end{array}$ \\
\hline 31 & $\begin{array}{l}\text { Stanton, Bayon, Neale, Ghali, } \\
\text { Benford, Cobb, Ingram, O'Malley, } \\
\text { Wilson, Pridmore, 2001 [62] }\end{array}$ & Language learning & Children age 5-7 & Storytelling by collaboration and drawing \\
\hline 32 & $\begin{array}{l}\text { Chipman, Druin, Beer, Fails, } \\
\text { Guha, Simms, } 2006 \text { [63] }\end{array}$ & $\begin{array}{l}\text { ICT collaboration technology } \\
\text { with a virtual trip to a national } \\
\text { park }\end{array}$ & Primary school & $\begin{array}{l}\text { Access and manipulate digital information } \\
\text { and artrifacts }\end{array}$ \\
\hline 33 & $\begin{array}{l}\text { Marshall, Cheng, Luckin, } 2010 \\
{[64]}\end{array}$ & Physics & University education & $\begin{array}{l}\text { Learning physics concept comparing physical } \\
\text { objects to manipulating graphical representa- } \\
\text { tions }\end{array}$ \\
\hline 34 & Fernaeus, Holander, 2006 [37] & Computer programming & $\begin{array}{l}\text { Primary school chil- } \\
\text { dreen age } 10\end{array}$ & Programimng by bodily action \\
\hline 35 & $\begin{array}{l}\text { Bakker, Antle, van den Hoven, } \\
2012 \text { [65] }\end{array}$ & music & Pre-school childreen & $\begin{array}{l}\text { Learning music by tangible and whole body } \\
\text { movement }\end{array}$ \\
\hline
\end{tabular}

